\title{
The Veiled Irreverence of the Italian Constitutional Court and the Contours of the Right to Silence for Natural Persons in Administrative Proceedings
}

\author{
Judgment of the Court (Grand Chamber) 2 February 2021, Case \\ C-481/19, DB v Consob, ECLI:EU:C:2021:84
}

Luigi Lonardo*

\section{INTRODUCTION}

$D B \vee C$ Conso $^{1}$ is the first case in which the Court of Justice of the European Union had to decide whether the right to silence is applicable to natural persons in the context of administrative proceedings which may lead to the imposition of a criminal penalty (in casu, on market abuse). Previously, the Court had had the occasion to adjudicate on the right to silence of legal persons in the area of market abuse or breach of competition law. ${ }^{2}$ The case also provided the Court with an opportunity to clarify an alleged discrepancy between its case law and that of the European Court of Human Rights. The latter appeared to recognise a broad content of the right to silence, including the right to remain silent on purely factual questions, whereas, in the field of competition law, the European Court of

*Lecturer in EU law, University College Cork. Visiting Lecturer, Paris School of International Affairs, Sciences Po. The author thanks the editors for their very useful comments.

${ }^{1}$ ECJ 2 February 2021, Case C-481/19, DB v Consob.

${ }^{2}$ ECJ 18 October 1989, Case C-374/87, Orkem v Commission, ECLI:EU:C:1989:387; ECJ 19 June 2006, Case C-301/04 P, SGL Carbon AG, ECLI:EU:C:2006:432.

European Constitutional Law Review, 17: 707-723, 2021

(C) The Author(s), 2021. Published by Cambridge University Press on behalf of European Constitutional Law Review. This is an Open Access article, distributed under the terms of the Creative Commons Attribution-NonCommercial-NoDerivatives licence (https://creativecommons.org/licenses/by-nc-nd/4.0/), which permits non-commercial re-use, distribution, and reproduction in any medium, provided the original work is unaltered and is properly cited. The written permission of Cambridge University Press must be obtained for commercial re-use or in order to create a derivative work.

doi: $10.1017 /$ S1574019621000365 
Justice had held that an undertaking which is subject to investigation has an obligation to answer such questions if the Commission requested it. ${ }^{3}$

The significance of the case goes beyond the novelty of the issue for EU law, as it also has an international law and an Italian constitutional law perspective. The European Court of Justice decision in Consob took place in the context of the debate on the levels of fundamental rights protection in Europe, as part of that complex and increasingly contentious encounter between national supreme or constitutional courts and the European Court of Justice, with the European Court of Human Rights being the third vertex. Each of these courts protects largely overlapping rights in deeply intertwined legal systems. Claims to the supremacy of one system over the others, or of the rulings of one court over the others, routinely clash with legal obstacles, political apprehensions, and, possibly, with someone's amour propre. Occasionally, the result of the clash is a most welcome increase in the standard of protection of fundamental rights, as in the case at hand.

The Consob judgment stems from 'doubts' harboured by the Italian Constitutional Court and the Italian Court of Cassation over the compatibility of EU secondary law with the Italian constitution, the EU Charter of Fundamental Rights (the Charter), and Strasbourg case law. ${ }^{4}$ Is the right to silence applicable to natural persons in administrative proceedings on market abuse and does it cover the right not to reply even to merely factual questions, as the Italian Constitution and the European Convention on Human Rights appear to mandate, or, as the Court of Justice of the European Union's case law seemed to indicate, is it confined to legal persons and only covers the right not to selfincriminate? The European Court of Justice's Consob decision ought to be read in light of the exceptionally unambiguous order for reference by the Italian Constitutional Court, in which the referring court strongly suggested the 'correct' answer - with which the European Court of Justice ultimately agreed. There are two features which, when considered jointly, make this order for reference somewhat exceptional. First, the Constitutional Court recalled the view of the Court of Cassation $^{5}$ - with which it concurred. This signalled that not one, but two Italian

${ }^{3}$ GC 20 February 2001, Case T-112/98, Mannesmannröhren-Werke AG, ECLI:EU:T:2001:61, paras. 77-78; SGL Carbon $A G$, ibid., paras. 44-49.

${ }^{4}$ Italian Constitutional Court, ordinanza 117/2019, paras. 7.1 and 7.2. In the reasoning set out in the order for reference, the Italian Constitutional Court - voicing concerns also from the Court of Cassation - questioned the compatibility of EU secondary law (and the Italian law transposing it) with the following provisions: Art. 6 ECHR, Arts. 47 and 48 EU Charter, Arts. 24(2) and 111(2) of the Italian Constitution, and Art. 14(3)(g) of the International Covenant on Civil and Political Rights.

${ }^{5}$ On this matter, the Court of Cassation had made a reference to the Constitutional Court, as now required by Italian law. On this procedure see more below, text accompanying n. 12 . 
apical courts believed the correct solution to be an extension of the right to silence to natural persons, also covering the right not to reply to questions on merely factual circumstances, which may later be used to build a case against the person. Second, the order for reference went into some detail to consider the Strasbourg and the Luxembourg Court's case law and provided its own interpretation of that case law to reach a conclusion which is in line with the European Convention on Human Rights, with EU law, and with the Italian constitution. ${ }^{6}$ The order did not merely set out a reasoning: it also drew the conclusion. ${ }^{7}$

This author styles such a request as a case of 'veiled irreverence': if there was a disagreement over the authority of the Court of Justice of the European Union, this was not expressed in overtly defiant terms as it has been in other instances. ${ }^{8}$ Instead, the preliminary reference took the form of a 'polite suggestion', by the Italian Court, of what the European Court of Justice should find. In light of the context and the detailed reasoning spelt out in the order for reference, ${ }^{9}$ this author suggests that the Italian Constitutional Court did not merely ask a question: rather than seeking advice, the Italian Court was giving it. To be sure, this may happen in the context of preliminary proceedings, but this is not how the procedure usually works, nor it is the objective for which it was originally designed. ${ }^{10}$ Interestingly, the preliminary reference in Consob follows a 're-centralisation' of constitutional adjudication operated by the Italian Constitutional

\footnotetext{
${ }^{6}$ Orders for reference do not usually contain detailed views, let alone such convincingly reasoned 'answers' (the information note on references from national courts for a preliminary ruling states in Art. 23 that 'the referring court may, if it considers itself able, briefly state its view on the answer to be given to the questions referred for a preliminary ruling'). For an exception, see the Danish Supreme Court's decision of 22 September 2014, Case 15/2014, Dansk Industri and comment by R. Holdgaard et al., 'From Cooperation To Collision: The ECJ's AJOS Ruling and The Danish Supreme Court's Refusal to Comply', 55(1) CMLR (2018) p. 17 at p. 20.

${ }^{7}$ See Italian Constitutional Court, ordinanza 117/2019, para. 9.2.

${ }^{8}$ Cases of overt defiance are the Slovak Pensions judgment of the Constitutional Court of the Czech Republic 2012/01/31 - Pl. ÚS 5/12 declaring ultra vires a judgment of the ECJ; the PSPP judgment of the German Constitutional Court, declaring an ECJ judgment ultra vires (BVerfG, Judgment of the Second Senate of 5 May 2020 - 2 BvR 859/15); or the Polish Constitutional Tribunal in Sygn. akt P 7/20, declaring that interim measures ordered by the ECJ are contrary to the Polish constitution.

'Italian Constitutional Court, ordinanza 117/2019, on which see the 'Background' and 'Analysis' sections of this case note.

${ }^{10} \mathrm{On}$ strategic uses of preliminary references, see J. Claassen, 'Assessing the Strategic Use of the EU Preliminary Ruling Procedure by National Courts', in B. Baade et al. (eds), Cynical International Law? Abuse and Circumvention in Public International and European Law (Springer 2021) p. 177 194.
} 
Court, and reconstructed also in the pages of this Review, ${ }^{11}$ which empowers the Constitutional Court to draft more requests for preliminary rulings than before. ${ }^{12}$ It will be recalled that the Constitutional Court was in fact also voicing the Court of Cassation's view.

We may see more of such references in the future, ${ }^{13}$ because the Italian Constitutional Court has used this strategy before: inserting in a preliminary reference a sophisticated and plausible legal reasoning to induce the desired outcome, in the context of fundamental rights protection. ${ }^{14}$ If this author's interpretation is correct, and the Italian Constitutional Court wants to be recognised as an equal partner together with the Court of Justice of the European Union when it comes to determining the contents of fundamental rights, then Italian Court's strategy is subtle (and 'seductive') ${ }^{15}$ as it does not amount to a direct threat to the power or the reputation of the Court of Justice of the European Union. ${ }^{16}$ Nor, despite its veiled irreverence, does it issue an explicit 'warning' ${ }^{17}$ that, should the European Court of Justice not decide what the

${ }^{11}$ D. Tega, 'The Italian Constitutional Court in its context. A narrative', 17(3) EuConst (2021) p. 369, and D. Tega, La Corte nel Contesto. Percorsi di ri-accentramento della giustizia costituzionale in Italia (Bononia University Press 2020) p. 11.

${ }^{12}$ See Italian Constitutional Court, judgment 269/17, para. 5.2: if an Italian court considers a norm to be contrary to the Italian Constitution as well as to EU law, the Italian Constitutional Court appears to require Italian courts to refer a question of constitutional validity to Rome - unless those courts wish to make a preliminary reference to Luxembourg first. This empowers the Constitutional Court to phrase requests for preliminary ruling (as it happened in Consob). Previously, national courts were instead required (not merely allowed) to refer to Luxembourg first (so the question might have never reached the Constitutional Court).

${ }^{13}$ Consider ECJ 2 September 2021, Case C-350/20 INPS ECLI:EU:C:2021:659, delivered few months after Consob. The preliminary ruling was referred by the Constitutional Court, which, in turn, had been invested of the question by the Court of Cassation pursuant to the practice described in the previous footnote. In INPS, the Italian apical courts doubted the compatibility of Italian legislation with EU secondary law on childbirth and maternity allowance (and with Art. 34 Charter). In its judgment, the ECJ confirmed the interpretation suggested by the referring court, with the result of enhancing the entitlement to social security benefits as recognised by Art. 34 Charter and EU secondary law giving expression to it.

${ }^{14}$ See Italian Constitutional Court, ordinanza 24/2017 (the M.A.S. case), on which see, among others, G. Piccirilli, 'The "Taricco Saga": the Italian Constitutional Court continues its European journey', 14 EuConst (2018) p. 814.

${ }^{15} \mathrm{D}$. Sarmiento, 'The Consob Way - Or how the Corte Costituzionale Taught Europe (once again) a Masterclass in Constitutional Dispute Settlement', EU Law live, 17 April 2021, 〈https://issuu.com/eulawlive/docs/weekend_edition_54〉, visited 4 November 2011.

${ }^{16}$ Similarly Sarmiento, ibid.

${ }^{17}$ For such distinction between threat and warning see J Elster, 'Strategic Uses of Argument', in K.J. Arrow et al. (eds.), Barriers to the Negotiated Resolution of Conflict (Norton 1995) p. 236, building in turn on the classic T. Schelling, The Strategy of Conflict (Harvard University Press 1960); J. Elster, Explaining Social Behaviour (Cambridge University Press 2015): 'A threat is a statement by A 
Italian Court suggests, there will be 'consequences'. ${ }^{18}$ And yet, it gets the job done. The European Court of Justice found that Article 14(3) of Directive 2003/6/EC on market abuse ${ }^{19}$ and Article 30(1)(b) of Regulation 596/2014 on market abuse, ${ }^{20}$ read in the light of Articles 47 and 48 of the Charter, ${ }^{21}$ cannot command member states to criminalise natural persons who, in an investigation carried out in respect of them by the competent authority under that directive or that regulation, refuse to provide that authority with answers that are capable of establishing their liability for an offence that is punishable by administrative sanctions of a criminal nature, or their criminal liability. In the words of one John Lilburn uttered in 1637, and recalled as the critical event to establish the privilege against self-incrimination by Justice Warren in the US Supreme Court case of Miranda v Arizona, 'no man's conscience ought to be racked by oaths imposed to answer to questions concerning himself in matters criminal, or pretended to be so.'.22

\section{BACKGROUND}

The main proceedings in Case C-481/19, $D B$ v Consob before the Italian Corte Costituzionale (Constitutional Court) were the result of a reference made by the Italian Court of Cassation during proceedings between an individual, Mr D.B., and the Commissione nazionale per le società e la borsa (CONSOB, the national commission for listed companies and the stock exchange). The Court of Cassation harboured doubts ${ }^{23}$ over the constitutionality of Italian law ${ }^{24}$ implementing EU

that A will harm B if B does not do X. A warning is a statement by A that if B does X, something (bad) will happen to B'.

${ }^{18}$ An example of warning is the judgment by the Constitutional Court of the Czech Republic Pl. ÚS 29/09 ('if European bodies interpreted or developed EU law in a manner that would jeopardize the foundations of materially understood constitutionality and the essential requirements of a democratic, law-based state that are, under the Constitution of the Czech Republic, seen as inviolable, such legal acts could not be binding in the Czech Republic').

${ }^{19}$ Directive 2003/6/EC of the European Parliament and of the Council of 28 January 2003 on insider dealing and market manipulation (market abuse).

${ }^{20}$ Art. 30(1)(b) of Regulation (EU) No 596/2014 of the European Parliament and of the Council of 16 April 2014 on market abuse (market abuse regulation) and repealing Directive 2003/6/EC of the European Parliament and of the Council and Commission Directives 2003/124/EC, 2003/125/ EC and 2004/72/EC.

${ }^{21}$ Titled 'Right to an effective remedy and to a fair trial' and 'Presumption of innocence and right of defence' respectively.

${ }^{22}$ US Surpreme Court, Miranda v Arizona 384 U.S. 459 [1966].

${ }^{23}$ Italian Constitutional Court, ordinanza 117/2019, para. 1.

${ }^{24}$ Art. 187 quindecies of decreto legislativo n. 58 - Testo unico delle disposizioni in materia di intermediazione finanziaria, ai sensi degli articoli 8 e 21 della legge 6 febbraio 1996, n. 52 
secondary law which requires member states to penalise breaches of the obligation to cooperate with the authority responsible for market supervision (and, indirectly, it harboured doubts over the validity of that EU law in light of Article 6 of the European Convention on Human Rights and Article 47 of the Charter ${ }^{25}$ ).

In turn, the Italian Constitutional Court referred two preliminary questions on the interpretation and validity of EU secondary law which requires member states to penalise breaches of the obligation to cooperate with the authority responsible for market supervision. The provisions in question were Article 14(3) of Directive 2003/6/EC on market abuse and Article 30(1)(b) of Regulation 596/2014 on market abuse, which brought about the harmonisation of administrative sanctions in this field. ${ }^{26}$ In essence, the Italian Constitutional Court questioned the compatibility of those articles with the right to remain silent, as it derives from Articles 47 and 48 of the EU Charter, and Article 6 of the European Convention on Human Rights ${ }^{27}$ - and in case those provisions of secondary law were found to be compatible with the right to silence enshrined in the Charter and the European Convention on Human Rights, it asked for guidance as to the content of that right.

The relevant EU secondary law, as applicable ratione temporis to the main proceedings, provided that member states shall determine the sanctions to be applied for failure to cooperate in an investigation by a supervisory authority, ${ }^{28}$ and that member states shall, in accordance with national law, provide for competent authorities to have the power to take appropriate administrative sanctions and other administrative measures in relation to a 'failure to cooperate or to comply with an investigation, with an inspection or with a request ${ }^{29}$ for information from 'any person, including those who are successively involved in the transmission of orders or conduct of the operations concerned, as well as their principals, and if necessary, to summon and question any such person with a view to obtain information'. ${ }^{30}$

[Legislative Decree No 58 consolidating all provisions in the field of financial intermediation, within the meaning of Articles 8 and 21 of the Law of 6 February 1996, No 52] of 24 February 1998.

${ }^{25}$ Italian Constitutional Court, ordinanza 117/2019, para. 3.4.

26ECJ 20 March 2018, AG's Opinion, Joined Cases C-596/16 and C-597/16, Di Puma and Zecca, ECLI:EU:C:2017:669 para. 2.

${ }^{27}$ In the reasoning set out in the order for reference, the Constitutional Court also referred to Arts. 24 and 111 of the Italian Constitution, as well as to Art. 14 of the International Covenant on Civil and Political Rights, as incompatible with the EU secondary law in question (and the Italian law transposing it).

${ }^{28}$ Art. 14 of Directive 2003/6.

${ }^{29}$ Art. 30(1)(b) of Regulation No 596/2014.

${ }^{30}$ Art. 23 of Regulation No 596/2014, to which Art. 30 expressly refers. 
The Italian Constitutional Court referred two questions: first, whether the abovementioned EU secondary law was 'to be interpreted as permitting Member States to refrain from penalising individuals who refuse to answer questions put to them by the competent authorities and which might establish their liability for an offence that is punishable by administrative sanctions of a "punitive" nature. ${ }^{31}$ Second, if the answer to the first question was negative, whether those provisions of EU law were:

compatible with Articles 47 and 48 of the [Charter] - including in the light of the case-law of the Strasbourg Court on Article 6 European Convention on Human Rights and the constitutional traditions common to the Member States - in so far as they require sanctions to be applied even to individuals who refuse to answer questions put to them by the competent authorities and which might establish their liability for an offence that is punishable by administrative sanctions of a 'punitive' nature. ${ }^{32}$

\section{The Opinion of Advocate General Pikamäe}

In a tightly argued Opinion, Advocate General Pikamäe reformulated the questions so as to capture more explicitly what he considered to be an important clarification requested by the Italian Constitutional Court. ${ }^{33}$ The case law of the European Court of Justice provided for a limited right of legal persons to remain silent in administrative proceedings leading to criminal sanctions, a right which does not cover 'each and every purely factual question', ${ }^{34}$ but only those questions to which 'an answer from the undertaking (...) is in fact equivalent to the admission of an infringement'. ${ }^{35}$ In the Constitutional Court's reading, the case law of the Strasbourg Court stated something different: the right to silence applicable to natural persons covers also purely factual questions. Thus, the Constitutional Court sought to ascertain whether the right to silence of natural persons, under EU law, also covered the right not to answer factual questions. ${ }^{36}$

To answer that question - whether Articles 47 and 48 of the Charter are applicable to natural persons in administrative proceedings leading to the imposition of

\footnotetext{
${ }^{31} D B$ v Consob, supra n. 1, para. 27.

${ }^{32}$ ibid.

${ }^{33}$ ECJ, Opinion of AG Pikamäe in Case C-481/19, DB v Consob, ECLI:EU:C:2021:84, para.

34 ibid., para. 91.

${ }^{35}$ ibid., para. 92, referring to the criteria set out in ECJ 15 October 2002, Joined Cases C-238/99 P, C-244/99 P, C-245/99 P, C-247/99 P, C-250/99 P to C-252/99 P and C-254/99 P, Limburgse Vinyl Maatschappij and Others v Commission, EU:C:2002:582.

${ }^{36}$ Opinion, supra n. 33, para. 39, referring to para. 9.2 of the decision to refer.
} 47. 
criminal sanctions - the Advocate General took the view that that answer was to be found by reference to the case law of the Strasbourg Court on Article 6 of the European Convention on Human Rights, and not to the European Court of Justice case law: the latter concerned the field of competition law and only legal persons. ${ }^{37}$ On the other hand, the Strasbourg case law makes it clear that the right to remain silent is applicable to natural persons ${ }^{38}$ and that it also covers the right not to answer questions of fact. In this context, 'respect for the person and his freedom of determination, by preventing coercion by the public authorities in the formation of his will, lies at the heart of the purpose of the right to remain silent as envisaged by the ECtHR' ${ }^{39}$. Bearing in mind this rationale and objective of the right to silence under the Strasbourg case law, the Advocate General considered that:

the scope of the right of natural persons to remain silent in administrative proceedings which may lead to the imposition of a penalty of a criminal nature (...) also covers answers to questions of fact which do not necessarily imply a confession of guilt, provided that they have had a bearing on the statement of reasons underlying the decision adopted or the penalty imposed at the close of those proceedings. ${ }^{40}$

The Advocate General's Opinion also closely considered a distinction, drawn by the Strasbourg court in the context of criminal proceedings, ${ }^{41}$ between 'proceedings and penalties which fall within the "hard core of criminal law" and those that fall outside that category': for the latter category, the European Commission argued, the scope of the right to remain silent will not necessarily apply with its full stringency, and can thus be reconciled with the Luxembourg Court case law. ${ }^{42}$ In the Advocate General's Opinion, the European Commission's submission was not material in the case of penalties adopted in the fields of insider trading and market manipulation: penalties in these fields, as the Strasbourg Court held in Grande Stevens, ${ }^{43}$ did fall within the hard core of criminal law. ${ }^{44}$ In any event, he took the view that the right to remain silent could not be restricted because it lies 'at the heart of the concept of a fair trial'. We will come back to this issue in the Analysis section, below.

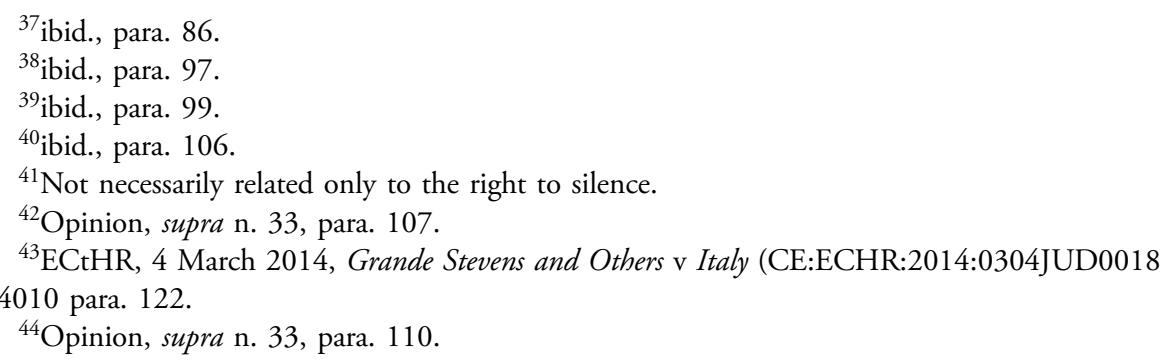


Further, the Advocate General took the view that it was necessary to scrutinise whether the phrasing of the EU secondary law in question permitted an interpretation in conformity with EU primary law. The Advocate General then argued that literal, systematic and teleological arguments individually (and, all the more so, cumulatively) supported the view that the norms of EU secondary law at issue could be construed so as to comply with the right to silence. ${ }^{45}$

\section{The JUdGMenT}

The Court recalled that the right to remain silent is recognised, by the Strasbourg Court, as lying at the heart of the notion of a fair trial. Since it is protected by Article 6 of the European Convention on Human Rights, ${ }^{46}$ the right is also to be given effect under EU law by virtue of Article 6(3) TEU and Article 52(3) Charter. ${ }^{47}$ The rationale for the guarantee is to ensure that the prosecution should establish 'its case without resorting to evidence obtained through methods of coercion or oppression in defiance of the will of the accused'. ${ }^{48}$ It would run counter to this rationale to impose criminal sanctions for the refusal to testify.

The Court took a broad view of the content of this right. It held that it covers not only confessions or indirect admissions of wrongdoing, but also information on questions of fact which may subsequently be used in support of the prosecution'. ${ }^{49}$ The Court also added an important caveat: the right cannot be invoked for every failure to cooperate with authorities, such as 'a refusal to appear at a hearing planned by those authorities or delaying tactics designed to postpone it'. ${ }^{50}$

As regards the scope of application of the right, the judgment stressed that this includes not only criminal proceedings, but also those which may lead to the imposition of administrative sanctions of a criminal nature (which is for the referring court to determine in light of three criteria: the legal classification of the offence under national law, the intrinsic nature of the offence, and the degree of severity of the penalty that the person concerned is liable to incur). ${ }^{51}$ Even beyond those cases, the right can be invoked when national legislation allows the evidence to be used in criminal proceedings. ${ }^{52}$

\footnotetext{
${ }^{45}$ ibid., paras. 62-84.

${ }^{46} \mathrm{DB}$ v Consob, supra n. 1, para. 38.

${ }^{47}$ ibid., para. 36.

48 ibid., para. 39.

${ }^{49}$ ibid., para. 40.

${ }^{50}$ ibid., para. 41.

${ }^{51}$ ibid., para. 42.

52 ibid., para. 44.
} 
The Court also clarified that its previous decisions on competition law could not be transposed to the present case, as the restriction of the right to silence applicable to undertakings and associations of undertakings in competition cases cannot be applied by analogy to determine the scope of the right to silence for natural persons subject of proceedings for an offence of insider dealing. ${ }^{53}$

Finally, the Court stressed that nothing in the EU secondary law at issue compelled the member states to impose (or not to impose) criminal penalties on natural persons for refusing to provide the competent authority with answers capable of being criminally sanctioned. Since the wording was open to more than one interpretation, the Court recalled that 'preference should be given to the interpretation which renders the provision consistent with primary law rather than to the interpretation which leads to its being incompatible with primary law. ${ }^{54}$

\section{AnALYsis}

\section{The veiled irreverence of the Italian Constitutional Court?}

The order for reference by the Italian Constitutional Court was phrased so as to leave little doubt as to what was the expected answer: both the Court of Cassation and the Constitutional Court suggested that the European Convention on Human Rights (Article 6), the Charter (Articles 47 and 48), and the Italian Constitution (Article 24) each mandate recognition of the right to silence in circumstances such as those in the main proceedings. The direct phrasing of the Constitutional Court, which built on a finely and tightly argued reasoning, signals perhaps a form of veiled irreverence to the authority of the European Court of Justice that has not drifted into conflict - but might have done so, one may speculate, if the European Court of Justice had reached a conclusion that was at odds with the right as protected by the Italian constitution. Consob is another example of the dialectic relationship between national and EU courts which is otherwise 'full of circumspection and deference'. ${ }^{55}$ Indeed, the questions and answer in Consob add an important example to the repertoire of cases of dialogue between apical national courts and the European Court of Justice. What this case illustrates is precisely one of the ways in which a constitutional court may interpret its role. ${ }^{56}$ By issuing a preliminary question which did not contain threats or warnings, the

53 ibid., paras. 46-48.

${ }^{54}$ ibid., para. 50.

${ }^{55}$ T. Tridimas, 'The ECJ and the National Courts. Dialogue, Cooperation, and Instability', in A. Arnull and D. Chalmers (eds.), Oxford Handbook of European Union Law (Oxford University Press 2015) p. 404.

${ }^{56}$ Sarmiento, supra n. 14. 
Italian court did not call into doubt the jurisdiction, authority or reputation of the European Court of Justice, but at the same time it obtained, in practice, a Court decision that was swayed in the direction it firmly suggested in a well-argued order for reference.

It is interesting to note that the Italian Constitutional Court has done all of this before. In important precedents such as Taricco ${ }^{57}$ and M.A.S., ${ }^{58}$ the Italian court made strongly suggestive orders for references to obtain a desired outcome from the European Court of Justice, and those cases also concerned standards of protection of fundamental rights. Indeed, other authors in this Review have explored at length the evolution of the recent case law of the Italian Constitutional Court in this context. ${ }^{59}$ It is to these standards that the analysis now turns with regard to the European Court of Justice's decision in Consob.

\section{The multi-level system of rights protection in Europe}

The judgment in Consob is an important piece in the puzzle of the multi-level protection of rights in Europe. The Italian Constitutional Court decided to refer a question also in light of a perceived discrepancy between the case law of the Court of Justice of the European Union and of the European Court of Human Rights. ${ }^{60}$ In a nutshell, while the Strasbourg case law entailed a broad protection of the right to remain silent, the jurisprudence of the Court of Justice of the European Union did not find that the right covered purely factual questions that are only indirectly liable to lead to self-incrimination. In the reconstruction of the referring court, this amounted to a significant limitation on the scope of that person's right not to self-incriminate by his or her statements. This is problematic because Article 52 of the Charter establishes that the meaning and scope of the rights which are protected by both the EU Charter and by the European Convention on Human Rights should be the same. ${ }^{61}$ Two observations are in order.

First, on the fundamental point of the breadth of the right, the European Court of Justice referred to the Strasbourg jurisprudence to decide that the right of natural persons does indeed also cover questions of fact. ${ }^{62}$ Significantly, in that crucial paragraph, the Court referred to the authority of Corbet and Others $\mathrm{v}$

${ }^{57}$ ECJ 8 September 2015, Case C-105/14, Taricco, ECLI:EU:C:2015:555.

${ }^{58}$ ECJ 5 December 2017, Case C-42/17, M.A.S., ECLI:EU:C:2017:936.

${ }^{59}$ G. Martinico and G. Repetto, 'Fundamental Rights and Constitutional Duels in Europe: An Italian Perspective on Case 269/2017 of the Italian Constitutional Court and Its Aftermath', 15 EuConst (2019) p. 731; and Tega (2021), supra n. 11.

${ }^{60}$ Italian Constitutional Court, ordinanza 117/2019, para. 9.2.

${ }^{61}$ See also Italian Constitutional Court, ordinanza 117/2019, para. 3.4.

${ }^{62} D B$ v Consob, supra n. 1, para, 40. 
France, ${ }^{63}$ a case where the Strasbourg Court was called upon to adjudicate on the right to silence in criminal proceedings (not in administrative ones). The European Court of Justice's pronouncement in Consob thus appears to say that the case law on the right to silence developed in the context of criminal proceedings should validly be relied on also in administrative proceedings carrying criminal sanctions. However, the European Court of Justice did not engage with the case law of the Strasbourg Court in any detail, limiting itself, so to speak, to accepting the rationale and content of the right to silence as derived from the interpretation of the Strasbourg court, without explaining why or with what exceptions (if any) the right to silence applies also in the context of administrative proceedings carrying criminal sanctions. The Opinion of Advocate General Pikamäe, instead, considered in much greater detail that jurisprudence, so much so that he greatly facilitates the readers' task of appreciating the (hidden) nuances of the reasoning and of the reach of the Grand Chamber's judgment. In line with the Strasbourg case law, the Advocate General's Opinion explains the distinction between criminal proceedings and administrative proceedings leading to the imposition of criminal sanctions, and recalls what test must be met for penalties to be considered 'of a criminal nature' ${ }^{64}$ In other words, since it reflects the reasoning of the Strasbourg Court, the Opinion might be relied upon, in the future, to draw even more precisely the boundaries of the right to silence in the context of administrative proceedings.

Second, what of the alleged discrepancy between the case law of European Court of Human Rights and of the Court of Justice of the European Union, then? On this equally fundamental point, it was not strictly speaking necessary for the European Court of Justice to take a position on how to reconcile the two, because the wording of the questions did not explicitly require it. But the European Court of Justice did so nonetheless, if implicitly, when it affirmed that its own earlier case law could not call into question the conclusion that the safeguards afforded by the second paragraph of Article 47 and Article 48 Charter include the right to silence of natural persons in criminal as well as administrative proceedings leading to the imposition of criminal sanctions. ${ }^{65}$ The reason why the two strands of case law can be reconciled is ultimately that the previous European Court of Justice decisions are applicable to legal persons; the Strasbourg case law and Consob, instead, concern natural persons. ${ }^{66}$ This is a crucial step in the reasoning of the Court. Again, the Opinion of the Advocate General enables the reader to fully appreciate a possible genesis of the differentiation of cases applicable to natural persons on one

\footnotetext{
${ }^{63}$ ECtHR 19 March 2015, No. 7494/11, Corbet and Others v France, para. 34.

${ }^{64}$ Opinion, supra n. 33, paras. 55-56.

${ }^{65} \mathrm{DB}$ v Consob, supra n. 1, para. 46.

66ibid., para. 48.
} 
hand, and to legal persons on the other. The answer is found once more in the reasoning of the Strasbourg Court: in its jurisprudence, the right to silence is predicated on the respect for 'human dignity and autonomy': the fact that legal persons are not humans makes it possible to deny them the right to remain silent under certain circumstances. ${ }^{67}$ In fact, in the context of other fundamental rights, the Strasbourg Court itself has sometimes distinguished between the level of protection granted to natural persons and that afforded to legal persons. ${ }^{68}$

As a secondary point, it might be worth pointing out that the judgment does not rely on the distinction made by the Strasbourg Court in Jussila v Finland between 'proceedings and penalties which fall within the "hard core of criminal law", which carry "significant stigma" for those affected by them, and those that fall outside that category. ${ }^{69}$ On that occasion, where the right to silence was not at stake, the Strasbourg Court held that, under Article 6 of the European Convention on Human Rights, Finnish authorities were allowed to dismiss the request for a hearing in a criminal case in the context of tax surcharges. The distinction was also relied on by the General Court in Schindler Holding and Others v Commission, ${ }^{70}$ but never by the European Court of Justice. ${ }^{71}$ This is a distinction on which the European Commission had tried to rely, arguing that the scope of the right to remain silent can be 'softened' (or 'tempered'), outside penalties falling into the hard core of criminal law; and therefore, the Commission argued, the protection guaranteed by the European Court of Justice's case law as regards the right to remain silent is perfectly in line with such tempered application. ${ }^{72}$ Such a reconstruction is unconvincing. First, the Commission's argument was not material for penalties adopted in the field of insider dealing and market manipulation. As the Advocate General recalled,

\footnotetext{
${ }^{67}$ ECtHR, 17 December 1996, No. 19187/91, Saunders v the United Kingdom, CE: ECHR:1996:1217JUD001918791, paras. 9 and 10 of the dissenting opinion of Judge Martens, joined by Judge Kūris. See also, for this thesis, W. Wils, 'Self-Incrimination in EC Antitrust Enforcement: A Legal and Economic Analysis', 26(4) World Competition: Law and Economics Review (2003) p. 577; and P. Oliver, 'Companies and their Fundamental Rights: a Comparative Perspective', 64(3) International and Comparative Law Quarterly (2015) p. 686.

${ }^{68}$ Opinion, supra n. 33, para. 99 and fn. 65 of the Opinion.

${ }^{69}$ ECtHR 23 November 2006, No. 73053/01, Jussila v Finland, CE: ECHR:2006:1123JUD007305301, para. 43.

${ }^{70}$ Case T-138/07, 13 July 2011, Schindler Holding and Others v Commission, EU:T:2011:362, para. 52.

${ }^{71}$ See instead reliance by the AGs in Opinion of AG Sharpston in Case C-272/09 P KME Germany and Others v Commission EU:C:2011:63 para. 67; Opinion of AG Mengozzi in Case C-521/09 P Elf Aquitaine v Commission EU:C:2011:89 paras. 30 and 31; and of Opinion of AG Kokott in Case C-501/11 P Schindler Holding and Others v Commission EU:C:2013:248 paras. 25-27.
}

${ }^{72}$ Opinion, supra n. 33, para. 107. 
the Strasbourg Court had already held in Grande Stevens that the penalties introduced by the Italian legislature to transpose Directive 2003/6 did fall within the hard core of criminal law. ${ }^{73}$ This is because of their financial severity, and because they gravely affect the professional reputation of the persons concerned. More generally, the Advocate General took the view that the right to remain silent could not be restricted as it lies 'at the heart of the concept of a fair trial'. ${ }^{74}$ Second, this author finds persuasive the Advocate General's view that Jussila did not, in any case, entail that the guarantees stemming from Article 6 of the European Convention on Human Rights could be limited or abolished for offences falling outside the hard core of criminal law, but merely that they could be replaced by alternative means of protecting the right to a fair trial. ${ }^{75}$ Semantic distinctions are crucial here: Jussila does not stand for the proposition that the right to fair trial can be limited or applied less strictly in the context of offences falling outside the core of criminal law, nor that the scope of such right can be narrowed down to such hard core cases. Such a view would be contrary to the rationale of Jussila, as the reasoning of the Strasbourg Court in that case shows, since it carried out an assessment to check whether guarantees were in place and whether therefore the dismissal of a request for a hearing could be allowed. ${ }^{76}$ Hence the Strasbourg Court held that, even outside the hard core of criminal law (such as in the case of tax surcharges), guarantees must be in place if the right to a fair trial is not to be breached. Without further specification by the Court, it is not possible to say whether the nuanced interpretation offered by the Advocate General has been accepted by the European Court of Justice and what, therefore, is that court's stance on the Jussila distinction and its consequences.

On the substance, the Court correctly recognised that the rationale for the protection of the natural person would be easily circumvented if refusal to answer questions was punishable with sanctions of a criminal nature, or with criminal prosecution. This is the case regardless of whether the proceedings are of a criminal nature, or whether they are administrative proceedings which national law couples with criminal sanctions (either by criminally sanctioning the refusal to cooperate, or by allowing criminal proceedings to begin, owing to evidence thereby gained). At the same time, the Court was careful to avoid going a step too far: the invocation of the right cannot constitute 'abuse' and justify any refusal to comply with the competent authorities. For example, the right to silence cannot be invoked simply to delay proceedings, or to serve a purpose other than that

\footnotetext{
${ }^{73} \mathrm{ECtHR} 4$ March 2014, Grande Stevens and Others v Italy, CE:ECHR:2014:030 4JUD001864010 para. 122.

${ }^{74}$ Opinion, supra n. 33, para. 113.

${ }^{75}$ ibid., para. 113 .

${ }^{76}$ Jussila v Finland, supra n. 69, paras. 47-48.
} 
for which it was conferred. ${ }^{77}$ In practice, however, the European Court of Justice gives important guidance to lawyers defending physical persons (and to the competent authorities): for once, hearings must be attended, and a refusal to appear or to cooperate is, prima facie, punishable. This presumption can be rebutted if the right to remain silent is invoked - and for such right to be successfully invoked, it must be done during proceedings capable of resulting in sufficiently serious penalties, and/or that punish an offence against a public good, also considering how the penalties are classified as criminal by national law (these are the criteria established by the European Court of Justice in Bonda ${ }^{78}$ ). The finding in Consob defining the contours of the right to silence for natural persons should be of wide application, as the rationale for the protection stands any time a natural person potentially faces criminal proceedings, or administrative proceedings leading to the imposition of criminal sanctions.

\section{The interpretation of EU secondary law in conformity with the Charter}

The Court and the Advocate General diverged meaningfully on the reasoning on the interpretation of the EU secondary law at issue in the light of the Charter. In this, the Advocate General's Opinion and the Grand Chamber evince not merely different hermeneutical views, but also significant variance in their constitutional outlook. ${ }^{79}$ In fact, the European Court of Justice - but not the Advocate General - appeared to take for granted that a conforming interpretation would be possible, whereas that possibility was itself questioned in the order for reference, which contained questions about the validity of EU secondary law, not merely about how to ensure an interpretation in conformity with the Charter. It should be recalled that the first question required the European Court of Justice to clarify whether the secondary law at issue could be interpreted as allowing member states not to punish persons for refusing to answer questions in administrative procedures which may lead to punitive sanctions: in case of affirmative answer, 'no doubt [would] remain as to the validity of those provisions in the light of [Article 47 and 48] Charter'. ${ }^{80}$ But by its second question, the Italian Constitutional Court sought to ensure that EU secondary law ${ }^{81}$ was compatible with the Charter: in other words, it was a question about validity. ${ }^{82}$

${ }^{77} D B$ v Consob, supra n. 1, para. 41.

${ }^{78}$ ECJ 5 June 2012, Case C-489/10, Bonda, ECLI:EU:C:2012:319.

${ }^{79} \mathrm{An}$ issue with consistent interpretation was also at the origin of the conflict in the Danish AJOS saga, on which see Holdgaard et al., supra n. 6, p. 32.

${ }^{80}$ Opinion, supra n. 33, para. 46 and Italian Constitutional Court, ordinanza 117/2019, para. 10.1

${ }^{81}$ Art. 14(3) of Directive 2003/6 and Art. 30(1)(b) of Regulation 596/2014.

${ }^{82}$ See also Opinion, supra n. 33, para. 45: 'the issue of the validity of the provisions at issue [...] is the subject of the second question'. 
The Advocate General was cautious as he did not assume automatically that EU secondary law could be interpreted in conformity with EU primary law. Instead, he considered carefully ${ }^{83}$ whether a systematic and teleological interpretation of that legislation imposed on member states the obligation to adopt criminal sanctions; he reached the conclusion that there was no such obligation, and for that reason the secondary law could be interpreted in a manner consistent with the right to remain silent. ${ }^{84}$ The Court (and the European Commission in its pleadings), instead, assumed that (these) secondary law provisions could indeed be interpreted consistently with the Charter, without explaining why this would be the case, and so went on to favour the interpretation that safeguarded such consistency. ${ }^{85}$ Admittedly, the principle that the provisions of secondary EU legislation must be interpreted in a manner consistent with fundamental rights is well-established in the Court's case law and was also codified by recital 44 of Directive 2003/6 (41) and recital 77 of Regulation No. 596/2014. And to be sure, EU secondary law enjoys a presumption of validity, ${ }^{86}$ but the second question referred by the Italian Constitutional Court hinged precisely on that validity. The European Court of Justice transformed a question on whether into a question on how. This evinces perhaps a hierarchical superiority of other (teleological, systematic) methods of interpretation over a literal one, i.e. that any provision of secondary law can be interpreted in conformity with the Charter. However, that is problematic, because if this is the case, the text of a provision might lose its relevance, and contra legem interpretations would be permitted.

In addition to the discrepancy in the case law of the Luxembourg and Strasbourg Courts discussed above, consider the following additional aspect of the central point raised by the Italian Constitutional Court on the divergence of standards in the protection of fundamental rights. ${ }^{87}$ Under Article 53 of the Charter, should the law of a member state be a relevant consideration when deciding on the possibility of interpreting EU secondary law in conformity with the Charter, when that national law protects higher standards than those provided by EU law? The Melloni ${ }^{88}$ answer is in the negative, and the Advocate General took the same view in Consob. This author agrees that, in this case, there was no need to deviate from what the European Court of Justice had held in Melloni. Implicitly, the European Court of Justice agreed with the view taken

\footnotetext{
${ }^{83}$ Opinion, supra n. 33, paras. $72-84$.

${ }^{84}$ ibid., para. 84 .

${ }^{85} \mathrm{DB}$ v Consob, supra n. 1, para. 50.

${ }^{86}$ ECJ 2 April 2020, Joined Cases C-715/17, C-718/17 and C-719/17, Commission v Poland, Commission v Hungary, Commission v Czech Republic, ECLI:EU:C:2020:257, para. 139.

${ }^{87}$ Italian Constitutional Court, ordinanza 117/2019, para. 10.1.

${ }^{88}$ ECJ 26 February 2013, Case C-399/11, Melloni, ECLI:EU:C:2013:107.
} 
by the Advocate General, but there was no discussion of these matters in the judgment.

\section{Conclusion}

The case of Consob stems from a request for preliminary ruling by the Italian Constitutional Court (in turn, fielded from the question by the Italian Court of Cassation), a request some may construe as somewhat irreverent for the authority of the Court of Justice of the European Union, in so far as it presents a question and a reasoned answer, strongly suggestive of the 'correct solution'. It formally respects the authority and competence of the Court of Justice of the European Union, and does not overstep procedural or substantive boundaries, while de facto leaving little margin for the European Court of Justice to reach a conclusion other than the recommended one.

As suggested by the Italian courts, in Consob the Court of Justice of the European Union recognised the right to silence of natural persons in the context of administrative proceedings which may lead to the imposition of penalties of a criminal nature. The decision is welcome in so far as it results in an expansion of the application of this fundamental right to natural persons - something which was not clear from the previous case law of the Court.

The contours of these rights have not been neatly delimited. It remains to be seen whether there are any exceptions to the right to silence in administrative proceedings, because the European Court of Justice did not venture into further detail on what is a penalty of a criminal nature (the Opinion of Advocate General Pikämae and the Strasbourg case law offer useful guidance on this point). While the Court reached the right conclusion on the substance (namely, that it was possible to interpret Article 14(3) of Directive 2003/6/EC on market abuse and Article 30(1)(b) of Regulation 596/2014 on market abuse in conformity with Articles 47 and 48 of the Charter), the reasoning is amenable to criticism in so far as it takes for granted what is instead an important step: in the judgment, the very possibility of interpreting those provisions in the light of the Charter is taken for granted without further explanation. If this practice were to be generalised, and it was always assumed that a provision, whatever its wording, can be interpreted consistently with the Charter, the text of a provision might lose its relevance, and contra legem interpretations would be permitted. 